\title{
Prevalence and Antibiotic Resistance of Escherichia coli 0157: H7 Serotype from Chicken Droppings Produced by Free - Ranged and Poultry Birds in Cross River, Nigeria
}

\author{
Nfongeh Joseph Fuh ${ }^{1}$, Owoseni Mojisola Christiana ${ }^{1,}$, , Adogo Lillian Yami ${ }^{2}$, Upla Peter Uteh ${ }^{1}$, \\ Ekpiken Solomon Ekpiken $^{3}$, Uchenwa Mercy Ogechi ${ }^{4}$ \\ ${ }^{1}$ Department of Microbiology, Faculty of Science, Federal University Lafia, Lafia, Nigeria \\ ${ }^{2}$ Department of Biological Sciences, Faculty of Science, Bingham University, Karu, Nigeria \\ ${ }^{3}$ Department of Biological Sciences, Faculty of Science, Cross River University of Technology, Calabar, Nigeria \\ ${ }^{4}$ Department of Microbiology, Faculty of Science, University of Calabar, Calabar, Nigeria
}

\section{Email address:}

dejoeman@yahoo.com (N. J. Fuh),moji.owoseni@gmail.com (O. M. Christiana), adogolillian@gmail.com (A. L. Yami), uplapeter90@gmail.com (U. P. Uteh), ekpikenekpiken@gmail.com (E. S. Ekpiken), ladymey26@yahoo.com (U. M. Ogechi)

${ }^{*}$ Corresponding author

\section{To cite this article:}

Nfongeh Joseph Fuh, Owoseni Mojisola Christiana, Adogo Lillian Yami, Upla Peter Uteh, Ekpiken Solomon Ekpiken, Uchenwa Mercy Ogechi. Prevalence and Antibiotic Resistance of Escherichia coli O157: H7 Serotype from Chicken Droppings Produced by Free - Ranged and Poultry Birds in Cross River, Nigeria. American Journal of Biomedical and Life Sciences. Vol. 6, No. 3, 2018, pp. $51-55$. doi: $10.11648 /$ j.ajbls.20180603.13

Received: May 23, 2018; Accepted: June 7, 2018; Published: July 21, 2018

\begin{abstract}
This study investigated the prevalence of Escherichia coli O157:H7 from chicken droppings produced by free ranged and poultry birds at different locations within Cross River State, Nigeria and their susceptibility to commonly used antibiotics. A total of 360 cloacal swab samples each were randomly collected from poultry (confined) and free ranged (unconfined) chickens. Standard cultural, biochemical, and serological (latex agglutination) methods were used to isolate $E$. coli $\mathrm{O} 157: \mathrm{H7}$. The isolates were subjected to antimicrobial susceptibility testing using disc diffusion method. Out of a total number of 360 anal swab samples collected from poultry and free-ranged chicken, 24 (6.67\%) strayed and $7(1.94 \%)$ poultry samples were positive for $E$. coli $\mathrm{O} 157: \mathrm{H} 7$ and the prevalence values differed significantly $(p<0.05)$ among the group of birds. Values for age category among the free-ranged birds also differed significantly $(p<0.05)$ with strayed chicks $(1-3$ weeks old) having highest value of $10.89 \%$. Out of the 9 isolates screened, $8(88.89 \%)$ were resistant to tetracycline, $7(77.78 \%)$ to ampicillin and nitrofurantoin and $6(66.67 \%)$ to chloramphenicol. All isolates were resistant to at least one antibiotic. This study reveals that the intestinal track of chicken harbors the bacterial pathogen hence interventions are needed to reduce transmission of $E$. coli $\mathrm{O} 157: \mathrm{H} 7$ via poultry products.
\end{abstract}

Keywords: Escherichia coli, Poultry, Antibiotic Resistance, Poultry Droppings

\section{Introduction}

Escherichia coli is documented as the most-studied bacterium [1]. The primary and secondary habitats of Escherichia coli are the intestinal tract of warm-blooded animals. In poultry, E. coli resides in the lower digestive tract, which it colonizes in the first $24 \mathrm{~h}$ after hatching [2]. Escherichia coli $\mathrm{O} 157: \mathrm{H} 7$ is a serotype of the bacterial species Escherichia coli and it is an important food borne pathogen of public health importance [3-4].

Poultry is a major fast growing source of food in the world today [5]. Poultry is an essential component of the Nigerian economy, providing income for small-scale farmers and a good source of high quality protein for the ever growing population of Nigeria. In livestock production, poultry occupies a prominent position in the provision of animal protein and this account for about $25 \%$ of local meat production in Nigeria [6]. 
Food pathogens cause more than three-hundred diseases [7-8]. Pathogens can be transmitted to humans directly through contact with poultry litter or indirectly through contaminated poultry products [9] The microorganisms present in the poultry droppings could be due to the contamination of the feed and water used in feeding the poultry fowl, contamination may also be caused by the micro flora of poultry attendants [10].

Antibiotic usage is considered the most important factor promoting the emergence, selection and dissemination of antibiotic-resistant microorganisms in both veterinary and human medicine [11]. Antimicrobial resistance among E. coli in food animals such as chicken is of increasing concern due to the potential for transfer of these resistant pathogens to the human population [12]. The intestinal track of poultry contains resistant bacteria and accordingly their faecal flora contains a relatively high proportion of resistant bacteria.

Consequently, the objectives of this study was to determine the prevalence of Escherichia coli O157:H7 from chicken droppings produced by free ranged and poultry birds in different locations within Cross River State and their susceptibility to commonly used antibiotics.

\section{Materials and Methods}

\subsection{Study Area}

This research was carried out in selected highly populated communities in Cross River State. The state is located in the Niger Delta Region, Southern Nigeria and it occupies an area of $299,10 \mathrm{~km}^{2}$ and an estimated population of 3,920,208 as at 2006 Nigeria population census [13]. It is bounded to the North by Benue State, to the West by Enugu and Abia States, to the East by the Republic of Cameroon and to the South by Akwa Ibom State and the Atlantic Ocean.

\subsection{Sampling Design}

The study area was mapped out according to political demarcations i.e. Northern, Central and Southern Senatorial Districts. Each senatorial district was further mapped out into two sampling areas each comprising of two local Government Areas found in the state. Each sampling area was designated SA.

\subsection{Sampling Procedures}

Sampling was restricted to communities within a particular sampling area during each sampling period. Bi-weekly sampling was performed during each sampling period. A total sampling duration of nine months was utilized with each area sampled three times for isolation of the pathogen giving a total of 18 sampling periods.

\subsection{Collection of Feacal Samples from Domestic Birds}

A total of 360 cloacal swab samples each were randomly collected from poultry (confined) and free ranged (unconfined) chicken. Five local poultry houses were randomly selected within each sampling area and visits made to obtain approval from the farm owners. Four birds were selected per poultry farm while the stray birds were sampled randomly from selected households during the night periods when they assembled to sleep. Information on the sex and age of each bird was provided by the farmer.

Each swab was immediately placed in Amies transport medium and kept in a flask with frozen ice packs $\left(4^{\circ} \mathrm{C}\right)$. The samples were immediately transported to the Microbiology laboratory for analysis within $24 \mathrm{~h}$.

\subsection{Sample Processing}

About $1.0 \mathrm{ml}$ of each stool samples suspension from transport medium was introduced into $10 \mathrm{ml}$ of buffered peptone water containing cefixime $(0.05 \mathrm{mg} / \mathrm{l})$ and vancomycin $(8.0 \mathrm{mg} / \mathrm{l})(\mathrm{BPW}-\mathrm{CV})$ and vigorously vortexed for 30 seconds to homogenize the mixture. It was then incubated at $37^{\circ} \mathrm{C}$ for 24 hours for enrichment.

The Enzyme-linked immunosorbent assay (ELISA) technique was used for the qualitative detection of $E$. coli O157 antigens in all enriched samples [14]. Two drops of each sample was introduced into separate wells until all the required number of wells (excluding the control wells) were used depending on the number of enriched samples to be assayed. Two drops of the positive and negative control solutions were also dropped into their respective wells. The contents were incubated at $37^{\circ} \mathrm{C}$ for 30 min and 2 drops of the enzyme conjugate added to each well. After a period of 30 min incubation, the contents were washed three times using deionized water and 2 drops of chromogen added to each with gentle shaking. The results were compared to those of the positive and negative control wells. A significant colour change to yellow indicated the presence of the $E$. coli O157 antigen bound by the anti-E. coli O157 antibodies impregnated in the wells. An optical density (OD) reading greater than 0.15 also confirmed a positive result.

All enriched samples with positive ELISA results were analyzed using the standard E. coli O157:H7 culture technique as recommended by [14]. All enriched, ELISA positive stool samples were serially diluted to $10^{-3}$ using physiological saline $(0.85 \% \mathrm{w} / \mathrm{v} \mathrm{NaCl})$. Approximately $0.1 \mathrm{ml}$ of $10^{-2}$ and $10^{-3}$ dilutions were spread plated on Sorbitol MacConkey agar supplemented with cefixime $(0.5 \mathrm{mg} / \mathrm{l})$ and potassium tellurite $(2.5 \mathrm{mg} / \mathrm{l})$ (SMAC-CT). All cultured samples were incubated overnight at $42^{\circ} \mathrm{C}$ for $24 \mathrm{~h}$. Sorbitolnegative colonies that appeared colourless to grey on SMACCT were considered positive for E. coli O157:H7. Three randomly selected suspected colonies were isolated on each plate and separately subcultured on nutrient agar slants and stored at $4^{\circ} \mathrm{C}$ in a refrigerator.

All positive colonies isolated on nutrient agar slants were further inoculated into test tubes containing $E$. coli with MUG (E. coli-MUG) medium and incubated at $42^{\circ} \mathrm{C}$ for 18 $24 \mathrm{~h}$. The broth cultures were then observed under ultraviolet (UV) light of long wavelength $(650 \mathrm{~nm})$ to detect the inability of E. coli $\mathrm{O} 157: \mathrm{H} 7$ to cleave MUG (about $92 \%$ of $E$. coli other than E. coli O157:H7 produce the enzyme 
glucoronidase which cleaves MUG to produce a blue fluorescent product). Positive isolates were considered as those that fermented lactose (yellow broth), produced gas (collected at the tip of the immersed Durham tubes) and did not produce any fluorescence. Other confirmatory biochemical tests typical to $E$. coli such as indole, methyl red, Voges Proskauer, Citrate and Lysine decarboxylase were also performed on the isolates.

Antigen typing was performed using standard E. coli O157:H7 antisera (Difco Laboratories, Detroit, Mich.) produced from rabbits and preserved with glycerol using 1:2 dilution. Slide agglutination technique was used to test resuscitated colonies directly from Sorbitol MacConkey agar (SMAC) as recommended by [16]. Colonies that agglutinated rapidly with the E. coli $\mathrm{O} 157: \mathrm{H} 7$ antisera were considered as confirmed positive E. coli $\mathrm{O} 157: \mathrm{H} 7$ colonies.

\subsection{Antimicrobial Susceptibility Testing}

The $E$. coli $\mathrm{O} 157: \mathrm{H} 7$ isolates were tested for antimicrobial susceptibility against eleven antibiotics using the disc diffusion method according to the Clinical Laboratory Standard Institute guidelines [17]. E. coli ATCC 25922 was used as a reference strain for quality control. The antibiotics disc included Amoxycillin $(48 \mu \mathrm{g} / \mathrm{ml})$, Ampicillin $(32 \mu \mathrm{g} /$ $m l)$, Ceftriaxone $(64 \mu \mathrm{g} / \mathrm{ml})$, gentamicin $(16 \mu \mathrm{g} / \mathrm{ml})$, cotrimozole $(25 \mu \mathrm{g} / \mathrm{ml})$, tetracycline $(30 \mu \mathrm{g} / \mathrm{ml})$, cefuroxime $(32 \mu \mathrm{g} / \mathrm{ml})$, ofloxacin, $(16 \mu \mathrm{g} / \mathrm{ml})$, ciprofloxacin $(8 \mu \mathrm{g} / \mathrm{ml})$, chloramphenicol $(32 \mu \mathrm{g} / \mathrm{ml})$ and Nitrofurantoin $(32 \mu \mathrm{g} / \mathrm{ml})$.

\subsection{Statistical Analysis}

The data were analysed with SPSS version 11.0 software (SPSS Inc, Chicago, IL). Percentages were compared using a Pearson chi square $\left(x^{2}\right)$ test for dependent samples or Fisher's extract " $t$ "- test where appropriate. Means were compared using the student " $t$ "-test for dependant samples.

The prevalence of $E$. coli $0157: \mathrm{H} 7$ strains from chicken droppings of free ranged and poultry birds were analyzed by statistical comparison of the survival values $(\log \mathrm{cfu} / \mathrm{ml})$ of all pairs using one-way analysis of variance (ANOVA: Jump in version 4.0.3, SAS institute Inc, Cary, N. C., USA) to determine significant differences at a probability level of 0.05 .

\section{Results}

The percentage prevalence of poultry birds had highest value of $3.33 \%$ from sampling areas 3 and 4 while no pathogen was isolated from samples obtained from sampling area 6 . No significant difference $(p>0.05)$ was observed in percentage prevalence among the poultry birds from various sampling areas as shown in Table 1.

Free-ranged birds had the highest percentage prevalence of $11.67 \%$ from sampling area 3 and least value of $3.33 \%$ from sampling area 6. Overall percentage prevalence of 1.94 and $6.67 \%$ were obtained for poultry and free-ranged chicken droppings, respectively. Though no significant difference ( $p>0.05$ ), was observed in the prevalence values among the free-ranged birds, the values between the confined (poultry) and free-ranged birds differed significantly $(\mathrm{p}<0.05)$.

The percentage prevalence of $E$. coli $\mathrm{O} 157: \mathrm{H} 7$ in poultry droppings had highest value of 3.33\% among the broilers (412 weeks old) and lowest value of $1.11 \%$ among the chicks (13 weeks old) and layers (18-72 weeks old) though no significant difference $(\mathrm{p}>0.05)$ was observed in the prevalence among the different age categories of the poultry birds.

Faecal droppings from free-ranged chicken had highest percentage prevalence of $10.89 \%$ among chicks (1-3 weeks old) and lowest value of $2.22 \%$ among the layers (18-72 weeks old). The percentage prevalence among the different age categories of strayed chicken differed significantly at $\mathrm{p}<0.05$. Prevalence values for both poultry and free-ranged chicken droppings according to age category are shown in Table 2.

Table 3 shows the susceptibility pattern of some commonly used veterinary antibiotics. Out of the 9 isolates screened, 8 $(88.89 \%)$ were resistant to tetracycline, 7 (77.78\%) to ampicillin and nitrofurantoin and $6(66,67 \%)$ to chloramphenicol. All isolates were resistant to at least one antibiotic while the highest resistance $(72.73 \%)$ was obtained with ICD1, ICD5 and ICD7. Total resistance of individual isolates to all antibiotic showed significant difference $(p<0.05)$.

Table 1. Prevalence of Escherichia coli O157:H7 in poultry and strayed chicken droppings from various sampling areas.

\begin{tabular}{lllll}
\hline \multirow{2}{*}{ Sampling Area } & \multicolumn{2}{l}{ Confined (Poultry) } & Strayed & \\
\cline { 2 - 5 } & No of samples & No of positive samples (\%) & No of samples & No of positive samples (\%) \\
\hline SA1 & 60 & $1(1.67)$ & 60 & $3(5.00)$ \\
SA2 & 60 & $1(6.67)$ & 60 & $5(8.33)$ \\
SA3 & $2(3.33)$ & 60 & $7(11.67)$ \\
SA4 & 60 & $1(3.33)$ & 60 & $4(6.67)$ \\
SA5 & 60 & $0(0.00)$ & 60 & $3(5.00)$ \\
SA6 & 60 & $7(1.94)$ & 60 & $2(3.33)$ \\
Overall prevalence & 60 & & 360 & $24(6.67)$ \\
\hline
\end{tabular}

Test of significance at $\mathrm{p}<0.05$

Table 2. Prevalence of Escherichia coli O157:H7 in strayed and confined chicken droppings according to age categories of birds.

\begin{tabular}{lllll}
\hline \multirow{2}{*}{ Birds category (Age in weeks) } & Strayed & Confined & \\
\cline { 2 - 5 } & Total number of samples & No of positive samples (\%) & Total number of samples & No of positive samples (\%) \\
\hline Chicks (1-3) & 101 & $11(10.89)$ & 90 & $1(1.11)$ \\
Broilers (4-12) & 112 & $6(5.36)$ & 90 & $3(3.33)$ \\
\hline
\end{tabular}




\begin{tabular}{lllll}
\hline \multirow{2}{*}{ Birds category (Age in weeks) } & Strayed & Confined & \\
\cline { 2 - 5 } & Total number of samples & No of positive samples (\%) & Total number of samples & No of positive samples (\%) \\
\hline Layers (18-72) & 90 & $2(2.22)$ & 90 & $1(1.11)$ \\
Old layer $(>72)$ & 57 & $5(8.77)$ & 90 & $2(2.22)$ \\
Total & 360 & $24(6.67)$ & 360 & $7(1.94)$ \\
\hline
\end{tabular}

Test of significance at $\mathrm{p}<0.05$

Table 3. Antibiotics susceptibility profile of E. coli O157:H7 chicken isolates on some commonly used antibiotics.

\begin{tabular}{|c|c|c|c|c|c|c|c|c|c|c|c|c|}
\hline $\begin{array}{l}\text { Antibiotics disc } \\
\text { content in } \mu \mathrm{g} / \mathrm{ml}\end{array}$ & $\begin{array}{l}\text { Diameter of } \\
\text { inhibition }(\mathbf{m m})\end{array}$ & ICD1 & ICD2 & ICD3 & ICD3 & ICD4 & ICD5 & ICD6 & ICD7 & ICD8 & ICD9 & $\begin{array}{l}\text { Total resistance } \\
(\%)\end{array}$ \\
\hline AMP & 32 & 17 & $12(\mathrm{R})$ & $0(\mathrm{R})$ & $0(\mathrm{R})$ & $19(\mathrm{~S})$ & $0(\mathrm{R})$ & $11(\mathrm{R})$ & $6(\mathrm{R})$ & $19(\mathrm{~S})$ & $9(\mathrm{R})$ & $7(77.78)$ \\
\hline AMX & 48 & 18 & $0(\mathrm{R})$ & $20(S)$ & $21(\mathrm{~S})$ & $23(\mathrm{~S})$ & $6(\mathrm{R})$ & $25(\mathrm{~S})$ & $19(\mathrm{~S})$ & $27(\mathrm{~S})$ & $11(\mathrm{R})$ & $3(33.33)$ \\
\hline CEF 1 (11.11) & 32 & 17 & $22(\mathrm{~S})$ & $18(\mathrm{~S})$ & $23(\mathrm{~S})$ & $28(\mathrm{~S})$ & $10(\mathrm{R})$ & $24(\mathrm{~S})$ & $20(\mathrm{~S})$ & $19(\mathrm{~S})$ & $21(\mathrm{~S})$ & $1(11.11)$ \\
\hline CFT 5 (55.56) & 64 & 35 & $38(\mathrm{~S})$ & $28(\mathrm{R})$ & $37(\mathrm{~S})$ & $39(\mathrm{~S})$ & $21(\mathrm{R})$ & $29(\mathrm{R})$ & $32(\mathrm{R})$ & $36(\mathrm{~S})$ & $30(\mathrm{R})$ & $5(55.56)$ \\
\hline CLM 6 (66.67) & 32 & 17 & $0(\mathrm{R})$ & $14(\mathrm{R})$ & $8(\mathrm{R})$ & $10(\mathrm{R})$ & $19(\mathrm{~S})$ & $23(\mathrm{~S})$ & $9(\mathrm{R})$ & $21(\mathrm{~S})$ & $11(\mathrm{R})$ & $6(66.67)$ \\
\hline COT $5(55.56)$ & 25 & 16 & $5(\mathrm{R})$ & $11(\mathrm{r})$ & $19(\mathrm{~S})$ & $7(\mathrm{R})$ & $0(\mathrm{R})$ & $21(\mathrm{~S})$ & $0(\mathrm{R})$ & $18(\mathrm{~S})$ & $23(\mathrm{~S})$ & $5(55.56)$ \\
\hline CPF 2 (22.22) & 8 & 21 & $24(\mathrm{~S})$ & $22(\mathrm{~S})$ & $27(\mathrm{~S})$ & $26(\mathrm{~S})$ & $18(\mathrm{R})$ & $29(\mathrm{~S})$ & $15(\mathrm{R})$ & $31(\mathrm{~S})$ & $21(\mathrm{~S})$ & $2(22.22)$ \\
\hline GEN 5 (55.56) & 16 & 15 & $10(\mathrm{R})$ & $0(\mathrm{R})$ & $18(\mathrm{R})$ & $20(\mathrm{~S})$ & $8(\mathrm{R})$ & $17(\mathrm{~S})$ & $6(\mathrm{R})$ & $23(\mathrm{~S})$ & $0(\mathrm{R})$ & $5(55.56)$ \\
\hline NTF 7 (77.78) & 32 & 17 & $15(\mathrm{R})$ & $13(\mathrm{R})$ & $8(\mathrm{R})$ & $0(\mathrm{R})$ & $27(\mathrm{~S})$ & $15(\mathrm{R})$ & $0(\mathrm{R})$ & $19(\mathrm{~S})$ & $12(\mathrm{R})$ & $7(77.78)$ \\
\hline OFX 2 (22.22) & 16 & 21 & $19(\mathrm{R})$ & $23(\mathrm{~S})$ & $27(\mathrm{~S})$ & $29(\mathrm{~S})$ & $24(\mathrm{~S})$ & $14(\mathrm{R})$ & $28(\mathrm{~S})$ & $30(\mathrm{~S})$ & $33(\mathrm{~S})$ & $2(22.22)$ \\
\hline TET 8 (88.89) & 30 & 19 & $0(\mathrm{R})$ & $11(\mathrm{R})$ & $17(\mathrm{R})$ & $8(\mathrm{R})$ & $10(\mathrm{R})$ & $13(\mathrm{R})$ & $15(\mathrm{R})$ & $15(\mathrm{R})$ & $22(\mathrm{~S})$ & $8(88.89)$ \\
\hline $\begin{array}{l}\text { \% Resistance } 51 \\
(51.52)\end{array}$ & & & 72.73 & 63.64 & 36.36 & 36.36 & 72.73 & 45.45 & 72.73 & 9.09 & 54.55 & $51(51.52)$ \\
\hline
\end{tabular}

Test of significance at $\mathrm{p}<0.05$

KEYS: AMP = AmpicIllin; AMX = Amoxicillin; $\mathrm{CEF}=$ Cefurantoin; $\mathrm{CFT}=$ Ceftriazone; $\mathrm{CLM}=\mathrm{Chloramphenicol}$; $\mathrm{COT}=\mathrm{Cotrimoxazole}$; $\mathrm{CPF}=$ Ciprofloxacin; TET=Tetracycline; GEN = Gentamicin; NTF = Nitrofurantoin; OFX = Ofloxacin; $\mathrm{S}=\mathrm{Sensitive}$; $\mathrm{R}=\mathrm{Resistant}$

\section{Discussion}

This study confirmed that confined and free-ranged chicken droppings were found to harbor E. coli $\mathrm{O} 157: \mathrm{H} 7$ with overall prevalence of $1.94 \%$ and $6.67 \%$, respectively. Though no significant difference $(p>0.05)$ was observed among the strayed birds, values between the confined and free-ranged birds differed significantly $(P<0.05)$. This may be due to regular administration of antibiotics by which most poultry farmers tend to protect the birds against infection. Ojo et al. confirmed the presence of $E$. coli $\mathrm{O} 157: \mathrm{H} 7$ strains in the faeces of poultry sampled from different farms in Nigeria [18]. In a similar study, [19] also reported 13 and 14\% level of $E$. coli O157:H7 from Lagos and Ibadan poultry farms, respectively.

In another study conducted in Nigeria by [20], the authors reported that $E$. coli was the most prevalent bacteria $(53.50 \%)$ isolated from Poultry droppings in Akure, Ondo State, Nigeria. A similar study conducted by [21] also reported that out of 194 cloacae samples examined for E. coli O157:H7 from Poultry farms in Ethiopia, 13.4\% were found to be positive for E. coli $\mathrm{O} 157: \mathrm{H} 7$. These variations may probably be due to the sampling techniques, geographical location, hygiene of the poultry farms, or the sensitivity of the microbiological technique used for isolation of the bacteria.

Significant difference $(p<0.05)$ was also observed in $E$. coli $\mathrm{O} 157: \mathrm{H} 7$ prevalence among the various age groups in free-ranged birds with the chicks (1-3weeks old) having the highest prevalence of $10.89 \%$. This agrees with the findings of [21] who reported a higher prevalence of $18.8 \%$ among young birds (less than six months) than adult birds with a prevalence of $7.5 \%$. This high prevalence among chicks between 1-3weeks old may be due to low immunity associated with young birds since all groups obtain food from the same source and were exposed to the same environmental conditions. Chadran and Mazumder observed that 93 E. coli isolates obtained from cloacal swabs and fresh droppings of 8 avian birds in British Columbia, Canada were carriers of stx2-gene [22]. Poultry meat has been shown to carry E. coli O157:H7 on its surface and the bacteria do persist in the caeca of experimentally infected chicks for as long as 11 months.

The antimicrobial susceptibility tests revealed that out of the 9 isolates screened against 11 commonly used veterinary antibiotics, there was resistance to tetracycline, ampicillin, nitrofurantoin and chloramphenicol. This agrees with the separate findings of [23-26] who reported resistance to these panel of antibiotics in poultry birds in China and Nigeria respectively.

\section{Conclusion}

The prevalence of E. coli $\mathrm{O} 157: \mathrm{H} 7$ was examined among poultry birds and free - range birds in Cross River State, Nigeria. This study confirms that confined and free-ranged chicken droppings harbor E. coli $\mathrm{O} 157: \mathrm{H} 7$ with the highest prevalence found among droppings of the free- ranged birds. All isolates of E. coli $\mathrm{O} 157: \mathrm{H} 7$ also exhibited antimicrobial resistance to a minimum of one antibiotics used in this study. Due to the relative increase in the consumption of chicken meat in the study area, extensive research is still required to establish the risk involved and to better understand the mechanisms of bacterial resistance to antimicrobial agents with emphasis on E. coli $\mathrm{O} 157: \mathrm{H} 7$ isolates. The cautious use 
of antibiotic is recommended, and alternative means of therapy like the use of probiotics should be employed to reduce antimicrobial resistance.

\section{References}

[1] C. P. Sousa "Escherichia coli as a specialized bacterial pathogen," Revista De Biologia E Ciências Da Terra, vol. 6, pp. 341-349, 2006.

[2] A. L. Ballou, R. A. Ali, M. A. Mendoza, J. C. Ellis, H. M. Hassan, and W. J. Croom, "Development of the chick microbiome: how early exposure influences future microbial diversity," Front Vet Sci. vol 3, 2016, doi: 10.3389/fvets.2016.00002.

[3] Y. Luo, S. Cui, J. Li, J. Yang, L. Lin, C. Hu, S. Jin, L. Ye, Q. Zhao, and Y. Ma, "Characterization of Escherichia coli isolates from healthy food handlers in hospital," Microbial Drug Resistance, 17. pp. 443-448, 2011.

[4] A. J. Stewardson, G. Renzi, N. Maury, C. Vaudaux, C. Brassier, E. Fritsch, D. Pittet, M. Heck, K. van der Zwaluw, and E. A. Reuland, "Extended-Spectrum $\beta$-LactamaseProducing Enterobacteriaceae in Hospital Food: A Risk Assessment," Infection Control \& Hospital Epidemiology, vol. 35, pp. 375-383, 2014.

[5] J. T. Hemen, J. T. Johnson, E. E. Ambo, V. S. Ekam, M. O. Odey, and W. A. Fila," Multi-antibiotic resistance of some gram negative bacterial isolates from poultry litters of selected farms in Benue State," International Journal of Sciences and Technology, vol 2, pp. 543-547, 2012.

[6] M. Agbaje, R. Davies, M. A. Oyekunle, O. E. Ojo, F. O. Fasina, and P. A. Akinduti, "Observation on the occurrence and transmission pattern of Salmonella Gallinarum in commercial poultry farms in Ogun State, South Western Nigeria," African Journal Microbiological Research, vol 4, pp. 796-800, 2010

[7] L. H. Gould, K. A. Walsh, A. R. Vieira, K. Herman, I. T. Williams, A. J. Hall, and D. Cole, "Surveillance for food borne disease Outbreaks-United States, 1998-2008", MMWR Surveill. Summ., vol. 62, pp. 1-34, 2013.

[8] A. H. Havelaar, M. D. Kirk, P. R. Torgerson, H. J. Gibb, T. Hald, R. J. Lake, N. Praet, D. C. Bellinger, N. R. De Silva, and N. Gargouri, "World Health Organization Global estimates and regional comparisons of the burden of food borne disease in 2010", PLoS Med. 12. e1001923, 2015.

[9] Z. Chen, and X. Jiang, "Microbiological safety of chicken litter or chicken litter-based organic fertilizers: a review," Agriculture, vol. 4, pp. 1-29, 2014.

[10] I. T. Mbata, Poultry meat pathogens and its Control. Internet Journal of Food Safety. 5 (7): 20-28, 2007.

[11] W. Witte, "Medical consequences of antibiotic use in agriculture," Science, 279, 996-7, 1998.

[12] J. A. Odwar, G. Kikuvi, J. N. Kariuki, and S. Kariuki, “A cross-sectional study on the microbiological quality and safety of raw chicken meats sold in Nairobi, Kenya," BMC Research. 7, article 627 doi: 10.1186/1756-0500-7-627, 2014.

[13] National Bureau of Statistics. Annual Abstract of Statistics, $23,2012$.
[14] D. G. Milley, and L. H. Sekia, “An Enzyme-linked Immunosorbent Assay-based isolation procedure for verotoxigenic E. coli." Appl. and Environ Microbiol. vol. 59, pp. 4223-4229, 1993.

[15] D. Warburton, and D. Christensen," Isolation of E. coli O157: H7 or NM in foods, MFLP-80. Health Canada. The compendium of analytical methods," Polyscience Publications, Laval, Quebec, Canada, 2006.

[16] N. Pradel, V. Lirelli, C. Champs, J. B. Palcoux, A. Reynaud, F. Cheutz, F. J. Sirot, B. Joly, and C. Forestier, "Prevalence and characterization of Shiga-toxin producing Escherichia coli isolated from cattle, food and children during a one-year prospective study in France," Journal of Clinical Microbiology, vol. 38, pp. 1023-1031, 2000.

[17] Clinical and Laboratory Standards Institute, "Performance Standards for Antimicrobial Disk and Dilution Susceptibility Tests for Bacterial Isolated from Animals; Approved Standard," Clinical and Laboratory Standards Institute, Wayne, PAUSA. Fourth Edition and Supplement, CLSI document VET01-A4 (standard) and VET01-S2 (supplement), 2013.

[18] O. E. Ojo, M. A. Oyekunle, A. O. Ogunleye, and E. B. Otesile, "E. coli O157:H7 in food animals in part of S/Western Nigeria: prevalence and in vitro antimicrobial susceptibility," Tropical Veterinarian, vol. 26, pp. 23-30, 2009.

[19] I. O. Olatoye, E. A. Amosun, and G. A. T. Ogundipe, "Multidrug resistant Escherichia coli O157 contamination of beef and chicken in municipal abattoirs of Southwest, “Nigeria Natural Sciences. vol. 10, pp. 125-132, 2012.

[20] O. A. Kehinde, and O. O. Funmilola, "Antibiotic Usage Pattern in Poultry and Resistance Pattern of Human Pathogenic Bacteria Isolated from Poultry Droppings in Akure, Nigeria," International Journal of Biomedical Science and Engineering, vol. 5, pp. 35-40, $2017 \mathrm{a}$.

[21] S. Mude, T. Naod, K. Jelalu, and M. Yimer, "Cloacael Carriage and Multidrug Resistance Escherichia coli $\mathrm{O} 157: \mathrm{H} 7$ from Poultry Farms, Eastern Ethiopia," Journal of Veterinary Medicine. Article ID 8264583, 2017.

[22] A. Chadran, and A. Mazumder, "Occurrence of Diarrheagenic Virulence Genes and Genetic diversity in Escherichia coli Isolates from feacal material of various Avian Hosts in British Columbia, Canada," Appl. Environ. Microbio., vol 80, pp. $1933-1940,2014$

[23] X. Chen, W., Zhang, J. Yin, N. Zhang, S. Geng, and X. Zhou, "Escherichia coli isolates from sick chickens in China: Changes in antimicrobial resistance between 1993 and 2013," Vet. Journ. vol. 202, pp. 112-115, 2014, pmid:25155303.

[24] D. Hailu, and G. Tefera, "Isolation and characterization of multidrug resistant Escherichia coli isolates from contagion syndrome poultry farm," Int. Journ. Cur. Tren. Pharmacobio. Med. Sci., vol. 1, pp. 19-26, 2016.

[25] A. K, Yassin, J. Gong, P. Kelly, G. Lu, L. Guardabassiand, L. Wei, "Antimicrobial resistance in clinical Escherichia coli isolates from poultry and livestock, China," PLOS ONE. vol. 12, e01853262017.

[26] O. A. Kehinde, and O. O. Funmilola, "Molecular Identification of Selected Multiple Antibiotic Resistance Bacteria Isolated from Poultry Droppings in Akure, Nigeria," Biochem. and Mol. Bio., vol. 2, pp. 6-11, 2017b. 